\title{
An Early Warning System in The Drinking Water System
}

\author{
Arif Imam Suroso ${ }^{1}$, Hamzah $^{2}$, Hendro Sasongko ${ }^{3}$ \\ \{arifimamsuroso@apps.ipb.ac.id ${ }^{1}$, hbst007@gmail.com², hendro.sasongko@unpak.ac.id ${ }^{3}$ \} \\ School of Business, IPB University Gedung SB-IPB, Jl. Pajajaran Bogor Jawa Barat, Indonesia $16151^{1}$, Faculty of \\ Economic, Pakuan Univesity Jl. Pakuan PO Box 452 Bogor 16143 Jawa Barat Indonesia ${ }^{23}$
}

\begin{abstract}
The research objective is to determine the critical factor parameters in the early warning system for drinking water companies using the Green Business Continuity Management (GBCM) approach and to design an early warning system model. This research uses a systems approach, which is a decision support system by involving experts in drinking water companies. The analytical method used is a fuzzy inference system (FIS) with four input variables in the GBCM indicator to determine a critical business activity, namely recovery time objective (RTO), the maximum tolerable period of disruption (MTPD), recovery point objective (RPO) and resource availability. The results of this study found that the scale of the RTO of an event must be overcome in less than 4 hours and tolerance of up to 8 hours, the MTPD criteria are almost similar to RTO, RPO as a description of the condition of how much clean water services are able to be secured and backup at the disruption, if the incident that needs to be recovered is small, only around 5\% (safe> 95\%) then the disturbance is still in the event category or condition is still secure> $90 \%$, then the incident and availability of resources are categorized if still available above $90 \%$, then the event is still in safe. This study also found the criteria and categories of events (events, incidents, crisis, and disaster). Based on the four indicators RTO, MTPD, RPO, and the availability of these resources with the FIS method produces 256 rule base "IF-THEN" to determine the level of crisis events in drinking water companies and produce an early warning system simulation model for decision-making status of the drinking water crisis.
\end{abstract}

Keywords: Decision Support System, Drinking Water, Early Warning System, Fuzzy Inference System, Green Business Continuity Management

\section{$1 \quad$ Introduction}

Water resources are one of the most useful resources for humans and for life in the universe. All humans need fresh water. Fresh water is a renewable resource, although clean water supply continues to decrease. Based on human needs that continue to increase in this era, water resources are lacking due to it's management inadequante so that conflicts of interest often occur in the region public [1].

The development of the quality and quantity of clean water is one of the development of environmental infrastructure that requires attention. Aside from 
being a vital resource, water is also a major cause of environmental problems experienced by residents, especially those living in urban areas. Even, the availability of water, especially clean water, is one of the determinants of the quality of life of a community [2].

Water management company is a service company that has a function to provide water supply labor services to support one of the objectives of Sustainable Development Goals (SDG'S), namely the availability of clean water access to the public with a universal target of access to clean water must be served by $100 \%$ by 2030 , with an estimated $80 \%$ served through pipelines. In 2016, it was found that the coverage of proper water services to drink in Indonesia through the piping system was $42.12 \%$. The level of water loss in the distribution network as a whole is $32.10 \%$ [3].

Since its function as a company must be able to meet the lives of many people. Drinking water management service companies are demanded to continue to maintain their consistency. However, this goal certainly has to face disturbances that can cause a decrease in the consistency of drinking water quality such as water scarcity experienced in the surface water, decreased river water discharge, weather changes that cause changes in water $\mathrm{pH}$, and decreasing the quantity of river water that is originally expected to be mainstay of raw water sources.

At present not only Indonesia is experiencing a clean water crisis, but almost all countries in the world are experiencing a clean water crisis. The amount of clean water in the world is only $1 \%$ that can be consumed, but all of them cannot be accessed easily [2]. The clean water crisis in Indonesia stems from the community's unconscious awareness of clean water management. The low availability of clean water has a negative impact on many sectors, one of which is the Health sector. Without access to hygienic drinking water can cause 3800 children die every day from the disease. Unicef [4] explains that the discovery of poor sanitation and hygiene behavior and unsafe drinking water contributes to $88 \%$ of child deaths due to diarrhea worldwide.

In general, the drinking water supply system is planned to meet current needs until next year's planning. This is because each water requirement varies greatly from each activity determined by various other factors including economic level, education level, water availability and so forth. One way to minimize failures in meeting drinking water needs is to use an Early Warning System 
(EWS). With early detection, the risks of failure can be anticipated effectively and efficiently.

Companies as industry players have contributed to the decline in the quality and quantity of resources on earth. Because of that condition, the company has a big role in improving the environment. Every policy made by a company must be oriented to the natural environment or commonly referred to as the Green Business Continuity Management. As regulated in the Regulation of the Minister of Environment No 11 of 2006 concerning Types of Business Plans and or Activities that Must Be Completed with an Analysis of Environmental Impacts.

Green Business Continuity Management (GBCM) or BCM based on environmentally friendly refers to the awareness of the importance and appropriateness of pollution prevention and the use of green technology [5]. GBCM is one of the approaches to overcome the problem of business disruption and $\mathrm{BCM}$ itself is a process of maintaining the continuity of operations or critical business processes when a business is experiencing disruption. GBCM requires knowledge, knowing how and practical experience regarding environmental control can be quickly transferred within GBCM [6].

This study discusses the early warning system in drinking water management service companies, with the aim of the study is to determine the parameters of critical factors in the early warning system for drinking water management with the Green Business Continuity Management (GBCM) approach and to design a model of early warning system in drinking water management companies.

\section{$2 \quad$ Literature Review}

\subsection{Natural Disaster Mitigation}

Mitigation is a series of efforts to reduce disaster risk, both through physical development and awareness raising and capacity to face threats. Disaster is an event or series of events that threaten and disrupt people's lives and livelihoods caused, both by natural and/or non-natural factors as well as human factors, resulting in human casualties, environmental damage, property losses, psychological impacts [7].

Disaster risk is the potential loss caused by a disaster in an area and a certain period of time which can be in the form of death, injury, illness, life 
threatened, loss of security, displacement, damage or loss of property, and disruption of community activities [8]. If this effort is increased into a policy, the effort is aimed at securing all government assets including all development proceeds that have been carried out so that they are not damaged, so that development results will continue to be utilized by the wider community. According to Diposaptono [9] and Latief [10], disaster mitigation efforts can be carried out in two ways, namely structural or physical (Hard/Soft Solution) efforts which are often called hardware and non-structural / non-physical efforts, also called software.

\subsection{Early Warning System}

Early warning is a combination of technological capability and the ability of the community to follow up on the results of the early warning. Early warning is part of reducing risk not only about technically accurate warnings, but must also build a good risk understanding of warnings, establish relationships between providers and warning users, and also increase the ability of authorities and communities to react correctly to early warnings.

EWS is an analytical model used to anticipate or minimize the impact of a crisis, which can be estimated in time regarding several risk indicators that behave abnormally. According to Kaminsky, Lizondo, and Reinhart [11] explain that the early warning system is a model that has benefits for economic actors to minimize the impact of a systemic crisis risk and provide space for anticipatory action.

In water resources management, generally an early warning system is aimed at flood control, especially in relation to the water level at either a floodgate or a dam. However, in this paper the early warning system is prioritized for water treatment plans (WTP) and drinking water management companies. Thus the function of the Early Warning System is prioritized so that the sustainability and availability of drinking water supplied by drinking water companies is guaranteed and safe.

\subsection{Business Continuity Management (BCM)}

Business Continuity Management is the process of maintaining the continuity of operations or critical business processes when a business experiences problems. Seow [12] considers BCM as a management of disaster risk which includes roles, policy, process, and governance with the aim of maintaining the continuity of the most critical business processes so that losses 
caused by disasters can be minimized. According to Seow [12], the steps that must be taken in developing and implementing an effective BCM are as follows: 1) Programme Management, 2) Risk Analysis and Business Impact Analysis (BIA), and 3) Identify Response Options.

\subsection{Green Business Continuity Management (GBCM)}

GBCM refers to the awareness and importance of pollution prevention and green technology [5]. Green business continuity management requires knowledge, knowing how and practical experience regarding environmental control can be immediately transferred within the GBCM. However, several factors such as irregularities in environmental engineering, lack of awareness of innovation engineering protection, and the diversity of participants from GBCM itself in knowledge and technology will cause technical risk of information or communication conflicts in the adoption of GBCM. The main factor is the lack of environmental awareness is a latent risk, so there is the need for GBCM. GBCM is a $\mathrm{BCM}$ that prioritizes the concept of environmentally friendly and sustainable technology. So that the GBCM requires knowledge, know-how and practical experience about environmental control that is quickly transferred to the GBCM [13].

\subsection{Fuzzy Inference System}

The basic principle of fuzzy logic control is actually very simple. If the conventional controller, the system being controlled is analytically modeled by a number of differential equations whose solution determines the control actions that must be given to the system, then fuzzy logic control is based on a logic model that represents the thinking process of an operator when controlling a system.

The concept of fuzzy logic was first introduced by professor Lotfi A Zadeh from the University of California, in June 1965. Fuzzy logic is a generalization of classical logic that only has two membership values, namely 0 and 1 . In fuzzy logic, the truth value of a statement ranges from being completely right to being completely wrong. With fuzzy set theory, an object can become a member of many sets with different degrees of membership in each set. This concept is different from the binary set theory (crisp). Binary set theory depends on twovalued logic to determine whether an object is a member of the set or not [14].

Fuzzy inference system (FIS) also called fuzzy inference engine is a system 
that can do reasoning with similar principles as humans do reasoning with their instincts. There are several types of FIS that are known, namely Mamdani, Sugeno and Tsukamoto [15]. The easiest FIS to understand, because it best suits human instincts, is FIS Mamdani. The FIS works based on linguistic principles and has a fuzzy algorithm that provides an approximation for mathematical analysis to enter. The input given to FIS is in the form of a certain number and the output produced must also be a certain number. The rules in linguistic language can be used as meticulous input, must be converted first, then do the reasoning based on the rules and convert the results of the reasoning into meticulous output.

In the Tsukamoto method, each consequence of IF-Then rules must be represented by a fuzzy set with a monotont membership function. As a result, the output of the inference results from each rule is given explicitly (crisp) based on $\alpha$-predicate (fire strength). The end result is obtained using a weighted average [16].

\subsection{Previous Research Review}

The importance of business continuity for business and organizational sustainability required the development of research aimed at developing the BCM concept. One of the studies on business continuity management came from Gang [13], which examined the Risk Evaluation of Business Continuity Management by Using Green Technology. The research explained that green technology innovation that developed into one of the expansion of research from technological innovation that was based on ecological and economic requlations. This also affects BCM and the use of green technology that has been used in BCM and makes it a new concept of Green Business Continuity Mangement (GBCM).

Hamzah, et al. [17] in his research stated that the quality of water that is "heavily polluted" is one of the categories of crisis leading to disaster based on Green Business Continuity Management criteria and can have an impact on vital or strategic business processes. This will threaten and impact the country on vital business (Core Business Process) especially the availability of raw drinking water (clean water crisis) and irrigation water. In addition, several factors, such as irregularities in environmental engineering, lack of awareness of the protection of innovation techniques, and the diversity of participants from GBCM itselt in knowledge and technology will cause technical risk of information within GBCM. 
Brocklehurst and Slaymaker [18] in their research stated that safe drinking water is water that is piped to the household at large. This aims to increase the amount of water available for both personal and domestic needs but also to provide water that meets water quality standards. The use of pipes to channel water requires competent governance and management of infrastructure to ensure sustainable service. But the shortcomings of using this pipe cannot overcome other environmental problems nor provide the expected health benefits.

Yulius and Suryani [19] explained that in overcoming the impact of disasters that arise, PDAM Kota Padang must have a comprehensive business continuity plan. So that if a disaster occurs again the company can minimize the impact that occurs and can then do the response more quickly and planned so that the water distribution to consumers does not experience disruption in a long time. The issue of Business Continuity Plan is growing due to the company's inability to face disasters.

Storey, Gaag, and Burns [20] in their study explained that technological advances have greatly influenced the monitoring of drinking water quality. One of the strategies adopted is an early report system in case of accidental or intentional contamination of water sourcecs. To ensure there is no increased risk in network operations, an early warning system must demonstrate operational compliance by focusing on water safety.

Levine, Liu, and Vince [21] explained that in the face of pollution conditions in the nuclear section of the river, the government implemented an early warning system with the aim of protecting water resources in an emergency, thereby ensuring a sustainable supply of safe drinking water for consumption. Without the right monitoring system, pollution will become a disaster.

\section{$3 \quad$ Methodology}

\subsection{Research Time}

Research activities include activities in the field through in-depth interviews and face validity of relevant experts conducted from February 2016 and December 2019. The research was conducted at drinking water management companies and water treatment processes from PDAM Bogor, PAM Jaya, PDAM Tangerang, Perpamsi, PJT 2 Jatiluhur Reservoir, PAL Jaya, and The Water Treatment Plant Manajer of PT Jababeka Infrastruktur. 
Several experts / key persons who were consulted were from the WTP Manager of PT. Jababeka Infrastruktur, Executive Director of Perpamsi / Former Director of PDAM Tangerang, Director of Paljaya, Technical Manager of PDAM Bogor, and Head of the Drinking Water Management Section of PJT II Jatiluhur. Expert judgment in the form of determining Event criteria are in accordance with RTO, MTPD, RPO, and the availability of resources in GBCM model for supplying raw water for drinking water treatment.

\subsection{Data Analysis}

This study uses primary data, in which primary data collection is based on expert/key person justification. Data are analyzed using the Fuzzy Inference System (FIS) method with the GBCM approach [5].

\subsection{Fuzzy Inference System (FIS) Method}

FIS is a process of formulating a mapping from input to output using fuzzy logic [22]. In general, the FIS consists of five functions, viz:

1. Rules $=$ contain a number of fuzzy If - Then rules.

2. Database $=$ defines the member function used.

3. Decision - making unit $=$ shows inference operation.

4. Fuzzyfication $=$ conversion of a single input to the appropriate linguistic value.

5. Defuzzyfication = converting fuzzy outputs to single-valued output (crisp).

The Sugeno type FIS model was first introduced in $1985 \mathrm{~s}$, by Takagi, Sugeno and Kang. The model is better known as the Takagi-Sugeno model [23]. Fuzzy rules in the Sugeno-shaped model:

$$
\text { "IF } X=A \text { and } Y=B \text { then } Z=F(X, Y) "
$$

$\mathrm{A}$ and $\mathrm{B}$ are fuzzy groups in antecedents; $\mathrm{Z}=\mathrm{F}(\mathrm{X}, \mathrm{Y})$ is a crisp function in consequence. $\mathrm{F}(\mathrm{X}, \mathrm{Y})$ is a polynominal with input variables $\mathrm{X}$ and $\mathrm{Y}$, the output of the Takagi-Sugeno model is linear or constant. In this study the ANFIS method will be used for simulation in evaluating risk.

\section{- Certainty Factor Theory}

In dealing with a problem, answers are often found that do not have full certainty. This uncertainty can be a probability or probability that depends on the 
outcome of an event. Uncertain results are caused by two factors, namely uncertain rules and uncertain user answers to questions raised by the system. Data collection and information besides distributing questionnaires, in-depth interviews are also conducted with experts. Researchers immediately ask criteria for Recovery Time Objective (RTO), Recovery Point Object (RPO), Maximum Tolerable Period of Disruption (MTPD) and Availability of Resources that are directly related to vital and critical business process functions. Certainty factors indicate the measure of certainty of a fact or rule. The certainty factor is defined as follows:

\section{$\mathrm{CF}[\mathrm{h}, \mathrm{e}]=\mathrm{MB}[\mathrm{h}, \mathrm{e}]-\mathrm{MD}[\mathrm{h}, \mathrm{e}]$}

with:

$\mathrm{CF}[\mathrm{h}, \mathrm{e}]=$ Certainty factor

$\mathrm{MB}[\mathrm{h}, \mathrm{e}]=$ Measure of trust of hypothesis $\mathrm{h}$, if given the evidence, e (between 0 and 1 )

$\mathrm{MD}[\mathrm{h}, \mathrm{e}]=$ Measure of mistrust of hypothesis $\mathrm{h}$, if given the evidence, e (between 0 and 1)

In Table 1 some fuzzy variables are used in detail from each activity.

Table 1. Description of the input variable

\begin{tabular}{lll}
\hline No & \multicolumn{1}{c}{ Input Variable Name } & \multicolumn{1}{c}{ Notes } \\
\hline 1 & Recovery Time Objective (RTO) & Target length of time to restore service for critical activities \\
2 & Recovery Point Object (RPO) & $\begin{array}{l}\text { How much is the transaction that can be secured and backed up in } \\
\text { the event of an interruption } \\
\text { The length of time of a paralysis of activity occurs due to } \\
\text { discoruption / disaster } \\
\text { Availability of resources when interference occurs } \\
\text { The length of time of a total shutdown of ICT when interterence } \\
\text { occurs }\end{array}$ \\
\hline
\end{tabular}

Input variables of Table 1 in this study will be adjusted the data in the field according to the quality, quantity and incidents in the field. The output of this FIS model is an assessment of the disturbance conditions that occur into several categories can be seen in Table 2 .

Table 2. Disruption category 


\begin{tabular}{ccc}
\hline No & Category / Condition & Symbol \\
\hline 1 & Event & 1 \\
2 & Incident & 2 \\
3 & Crisis & 3 \\
4 & Disaster & 4 \\
\hline
\end{tabular}

\section{Discussion}

\subsection{1. Determination of Critical Activity}

The reservoir has a function to supply raw material as a source for drinking water treatment. Thus, all risks that can threaten the function of the reservoir will cause inconsistencies with the treated drinking water. Therefore, preventive measures are needed to avoid events and minimize risks so that disasters do not occur [24].

Based on these risk predictions, it is very important for a company to implement GBCM so that potential threats to a business can be identified early. GBCM can provide a framework that aims to build organizational resilience. Thus the GBCM approach can become a strategy to minimize impacts arising from critical situations and not hamper water resource management activities in Jatiluhur Reservoir. Of course, the implementation of the GBCM strategy must be supported by the development of human resource capabilities and competencies that are owned as an innovation for sustainable business management [25].

The results of the risk assessment and its impact and how the contingency strategy (mitigation) of the green business impact analysis (GBIA) results above as the key output of the GBIA process should be measured and followed up again by determining how much the maximum acceptable outage (MAO) for each activity business / function. For example, how long can an activity be disrupted before the consequences become unacceptable to the organization? (Congtinency Solution PTY LTD 2012).

Maximum Acceptable Outage (MAO) is one important aspect to get input from senior management as a high-level perspective analysis that is likely to have a blackout effect for the organization as a whole. In obtaining a perspective on the decision of the MAO it is appropriate for a business to conduct a workshop or FGD with senior manager across divisions or different rea managers. This activity will provide checks and balances to keep the analysis as objective as possible. Therefore, it is expected that in the GBCM implementation and operational plans 
in Jatiluhur Reservoir, the top management must determine MAO, business impact profile, and business continuity needs.

The business risk rating that has been made needs to be reiterated when the business impact rating consists of the level, ranking, how big the impact of the risk is on the reputation and image of the company, stakeholders who will be affected, and the impact of these risks in compliance and legality. For example, for a low risk label with an insignificant ranking value it is known that the loss value is less than 50000 USD, it has a small impact and will not cause news to the company's reputation and image, the impact on stakeholders is not convenient and is only individually delayed and small compliance and legal impacts. Therefore, vital critical business processes with high money rating risks need to be simulated using the Fuzzy Inference System (FIS) approach.

Determination of critical business activities or early warning is done so that the business has work priorities that are able to ensure the sustainability of the business. On the other hand, determining critical cash activities can reduce the complexity of the problem domain being faced. After the critical activity is known, the next process is to identify the parameters of the activity flush that will be used as input to the FIS.

According to Hamzah [26] one of the vital and critical activities of the management of Jatiluhur Reservoir water resources is its function to supply raw water. Based on BCM theory in general there are five indicators that can determine whether a business is really critical or not, namely RTO, MTPD, RPO, Availability of Resources, and System Operation Failure (ICT) [24].

In the simulation model in this study it is only carried out on the function of the water provider for drinking, mainly related to the threat of quality and quantity that has reached a high risk rating (red), while for simulations the irrigation is not tried to make a simulation model, because it is difficult to determine the indicators of RTO, MTPD, RPO and availability of resources, for this reason an early warning system needs to be simulated. In detail, the problem domains of the four indicators for function as drinking water providers can be seen in Table 3 according to their critical levels. There are four indicators used as inputs in the FIS. 
Table 3. Event criteria are in accordance with RTO, MTPD, RPO, and the availability of resources in GBCM model for supplying raw water for drinking water treatment

\begin{tabular}{|c|c|c|c|}
\hline \multirow[t]{2}{*}{ Level } & \multicolumn{2}{|r|}{ Event / disturbance criteria } & \multirow[t]{2}{*}{ Criteria range } \\
\hline & \multicolumn{2}{|r|}{ RTO (hour) } & \\
\hline 1 & Event & \multicolumn{2}{|l|}{$<4$} \\
\hline 2 & Incident & \multicolumn{2}{|c|}{4 to 8 hours } \\
\hline 3 & Crisis & \multicolumn{2}{|c|}{8 hours to 72 hours } \\
\hline 4 & Disaster & \multicolumn{2}{|c|}{$>72$ hours } \\
\hline & \multicolumn{3}{|c|}{ MTPD (hour) } \\
\hline 1 & Event & \multicolumn{2}{|l|}{$<4(1-2)$} \\
\hline 2 & Incident & \multicolumn{2}{|c|}{4 to 8 hours } \\
\hline 3 & Crisis & \multicolumn{2}{|c|}{8 hours to 72 hours } \\
\hline 4 & Disaster & \multicolumn{2}{|l|}{$>72$ hours } \\
\hline \multicolumn{4}{|c|}{$\mathrm{RPO}(\%)$} \\
\hline 1 & Event & \multicolumn{2}{|l|}{1 s.d $5 \%$} \\
\hline 2 & Incident & \multicolumn{2}{|l|}{6 to $10 \%$} \\
\hline 3 & Crisis & \multicolumn{2}{|l|}{10 to $30 \%$} \\
\hline 4 & Disaster & \multicolumn{2}{|l|}{$>30 \%$} \\
\hline & \multicolumn{3}{|c|}{ Availability of Resources (\%) } \\
\hline 1 & Event & $>90 \%$ & $(90-100)$ \\
\hline 2 & Incident & $80-90 \%$ & $(80-90)$ \\
\hline 3 & Crisis & $75-80 \%$ & $(75-80)$ \\
\hline 4 & Disaster & $<75 \%$ & $(<75)$ \\
\hline
\end{tabular}

The results of the range of criteria for Table 3 are based on expert verification, especially those experienced in water management for drinking from PJT II, Jababeka Infrastruktur, PDAM and PAM Jaya as well as PERPAMSI. From the criteria, it is used as a reference making rule base. Based on Table 1, the RTO indicator or the time needed for business process recovery in order to function normally (back to normal) is: (1) If an event can be resolved in less than four hours ( $<4$ hours), then the event / disturbance criteria is categorized as event, (2) If an incident can be overcome for between 4 to 8 hours, the criteria for the event / disturbance is categorized as incident, (3) If an event can be overcome for between 8 to 72 hours, the criteria for the event / disturbance is categorized as crisis, whereas if the event cannot be resolved for more than 72 hours, the criteria is considered to be disaster. Whereas for the maximum period of disturbance that can be tolerated or the maximum tolerable period of disruption, the criteria are almost similar to RTO.

$\mathrm{RPO}$ or the purpose of the recovery point is to provide a description of the condition of the transaction that can be secured and backed up in the event of a 
disruption. If the events that need to be recovered are only around 1 to 5\% (conditions are still safe > 95\%) then the disturbance is still in the event category. If the incident that needs to be recovered is only around 6 to $10 \%$ (condition is still secure > 90\%) then the disturbance is still in the incident category. If business conditions need to be recovered for around $10-30 \%$ (secure condition is around $70-90 \%$ ), then this event is considered as crisis, whereas if business transaction conditions are not secure less than $70 \%$ (must recover business for more than $30 \%$ ) then the event already considered to be disaster.

The next indicator is the availability of resources, namely water resources, that is, the availability raw water. If the resources (available raw water) are still above $90 \%$ (> 90\%), then the event is still in the event category (normal). If the availability of raw water resources is only around $80-90 \%$, then the incident can be categorized as incidental, if the availability of water resources is only around $75-80 \%$, then it can be categorized as a crisis, and the availability of water resources is less than $75 \%$, then it is considered to occur the disaster. Based on the four indicators, a rule base is made with four inputs, namely RTO, MTPD, RPO, and Availability of Resources with each input having four criteria and conditions, explained in detail as follows.

\subsection{Basis of Rules}

In calculating fuzzy data with FIS, IF ...THEN......rule is used. The rules are made based on expert opinions obtained through interviews as described in Table 1. The number of rules matches the number of criteria and parameters. In this study, there are four (4) criteria, namely RTO, MTPD, RPO, and Availability of Resources. Each criterion has four (4) parameters (membership function) so the number of rules is $4^{4}=256$ rules. In the FIS architecture, the rules are formed adaptively according to the characteristics of the data entered. The rule base example below illustrates four rules in Table 4, more complete there are 256 rules (rule base).

For rule- 1 on the basis that if the RTO $<4$ hours, then the event is an event and if the MTPD is also $<4$ hours, then the event $=$ event and if the RPO $<=5 \%$, then the event $=$ event and the availability of resources $>90 \%$, then it is the event. So rule- 1 is: 


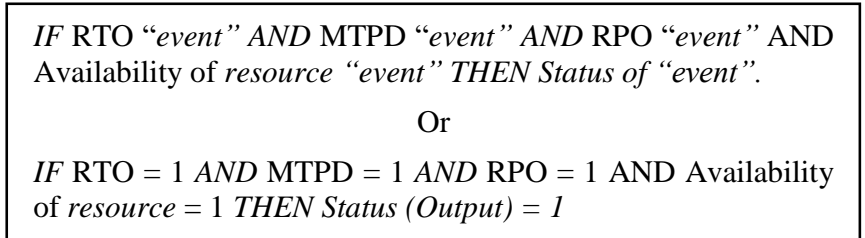

Thus the same method for the next rules, namely the 5th rule until the 256th rule with indicators and criteria in accordance with the input at the time. The input table based on the rule base of each RTO, MTPD, RPO, and Availability of Resources can be seen in detail in Appendix 1 in the form of a scale lifting 1 - 4 .

Table 4. Example of a rule base for the critical determination of GBCM model

\begin{tabular}{|c|c|c|}
\hline No & Criteria IF & Output Category (Then) \\
\hline Rule-1 & $\begin{array}{l}\text { IF RTO event AND MTPD event AND RPO event AND Availability } \\
\text { of resource event } \\
\text { Or } \\
\text { IF RTO }=1 \text { AND MTPD = } 1 \text { AND RPO = } 1 \text { AND Availability of } \\
\text { resource }=1\end{array}$ & $\begin{array}{l}\text { THEN Event } \\
\text { Or } \\
\text { THEN Status = } 1\end{array}$ \\
\hline Rule-2 & $\begin{array}{l}\text { IF RTO event AND MTPD event AND RPO event AND Availability } \\
\text { of resources incident } \\
\text { Or } \\
\text { IF RTO }=1 \text { AND MTPD = } 1 \text { AND RPO = } 1 \text { AND Availability of } \\
\text { resource }=2\end{array}$ & $\begin{array}{l}\text { THEN Event } \\
\text { Or } \\
\text { THEN Status = } 1\end{array}$ \\
\hline Rule-3 & $\begin{array}{l}\text { IF RTO event AND MTPD event AND RPO event AND Availability } \\
\text { of resource crisis } \\
\text { Or } \\
\text { IF RTO }=1 \text { AND MTPD = } 1 \text { AND RPO=1 AND Availability of } \\
\text { resource }=3\end{array}$ & $\begin{array}{l}\text { THEN Incident } \\
\text { Or } \\
\text { THEN Status = } 2\end{array}$ \\
\hline Rule-4 & $\begin{array}{l}\text { IF RTO event AND MTPD event AND RPO event AND Availability } \\
\text { of resource disaster } \\
\text { Or } \\
\text { IF RTO }=1 \text { AND MTPD = } 1 \text { AND RPO = } 1 \text { AND Availability of } \\
\text { resource }=4\end{array}$ & $\begin{array}{l}\text { THEN Crisis } \\
\text { Or } \\
\text { THEN Status = } 3\end{array}$ \\
\hline ....... & . & THEN..... \\
\hline Rule-256 & $\begin{array}{l}\text { IF RTO disaster AND MTPD disaster AND RPO disaster AND } \\
\text { Availability of resource disaster } \\
\text { Or } \\
\text { IF RTO }=4 \text { AND MTPD }=4 \text { AND RPO }=4 \text { AND Availability of } \\
\text { resources }=4\end{array}$ & $\begin{array}{l}\text { THEN Disaster } \\
\text { Or } \\
\text { THEN Status = } 4\end{array}$ \\
\hline
\end{tabular}

\section{Description of the input variable:}

- RTO : Target length of time to restore 
service for critical activities

- RPO : How much is the transaction that can be secured and backed up in the event of an interruption

- MTPD : The length of time of a paralysis of activity occurs due to discoruption / disaster

- Availability : Availability of resources when

of interference occurs

Resources

\subsection{Fuzzy Inference System (FIS) Approach}

Fuzzy Inference System (FIS) is one method in overcoming uncertainty in decision making. FIS has been widely applied in many fields including managerial technology. Based on four (4) input parameters according to the rule base (Table 2) illustrated in the FIS editor menu as shown in Figure 1, while the membership function can be seen in Figure 2.

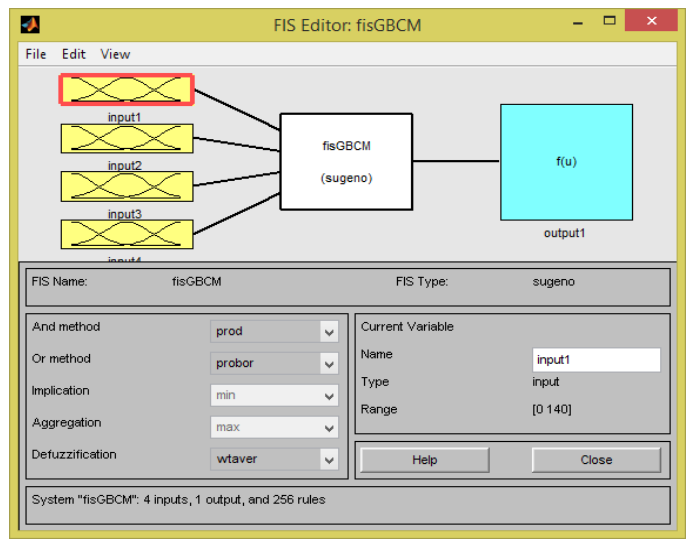

Figure 1. FIS editor with Sugeno method for four GBCM model inputs 


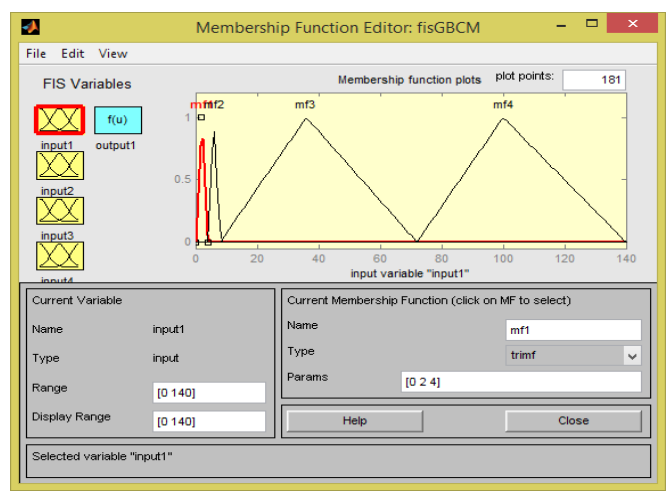

Figure 2. Membership function plot for four GBCM model inputs

After making sure it's correct, the next step is to run the program. Simplifying the program can be done by pressing the following button $D$, then the simulation interface window will appear to determine the critical determination of water resources with GBCM as shown in Figure 3.

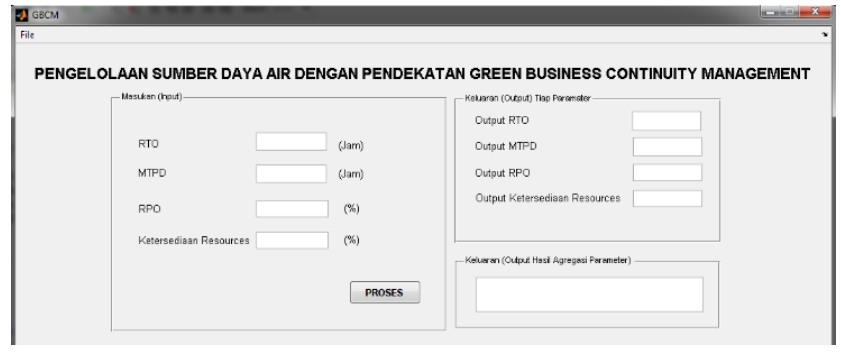

Figure 3. Simulation interface for several parameters of water resources, specifically in GBCM model drinking water treatment.

In order that the results can be visualized using the coloring, the following Table 5 provides the color illustration from each input category.

Table 5. Color illustration as output visualization

\begin{tabular}{llll}
\hline No & Output & Color & Visualization \\
\hline 1 & Event & Blue & \\
2 & Incident & Green & \\
3 & Crisis & Yellow & \\
4 & Disaster & Red & \\
\hline
\end{tabular}


The program code that must be typed (Figure 4):

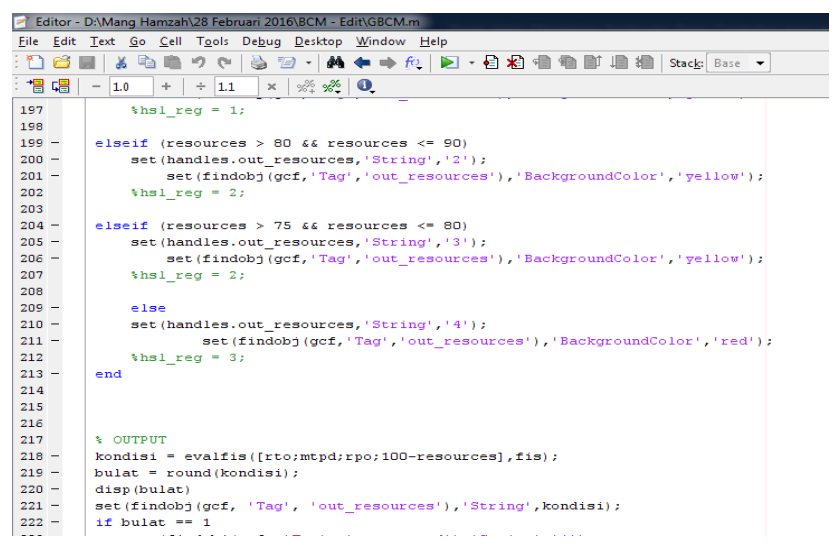

Figure 4. Program code to run the application

An example of the output of the simulation results can be seen in Figure 5 .

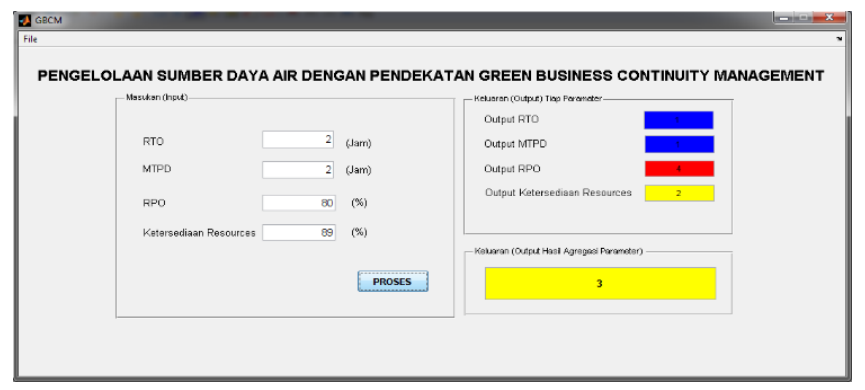

Figure 5. Example of the simulation output of the GBCM model

This GBCM model prediction simulation is actually part of a strategic approach to managing risk disorders as identification of responses and response options for events as early detection in BCM. Based on the results of the simulation steps and the next strategy can be done. This process includes the identification and evaluation of choices or alternatives responses to meet the needs of business continuity, including protection of Human Resources (HR), information, buildings and facilities, as well as data backup and offsite storage. The aim is to obtain the best response alternatives based on the results of the analysis (taking into account the pros and cons and the cost calculation). Response options for HR consist of segregation, redeployment, succession plans, and skills 
management [8]. In drinking water management companies or PDAMs, such an EWS system is needed to find out how big the impact of an interruption or event or damage has occurred and how big the impact is.

If the choices in responding to events, in the crisis category, then need to be followed up by building a response plan. This process consists of preparing a response team structure, establishing a process for disaster and escalation notification, and Business Continuity Plan documentation. In this process backup facilities and equipment begin to be prepared to prepare for the implementation of business continuity management.

\section{Conclusions}

Water resources are a very useful resource for humans and for life in this universe. A drinking water company is a service company that has a function to provide services for drinking water needs to support one of the goals of the Sustainable Development Goals (SDG'S), namely the availability of access to clean water for the community with a universal target of access to clean water that must be served by $100 \%$ by 2030 , with an estimated $80 \%$ of it served through pipelines. Because its function as a company that must be able to meet the needs of many people. Drinking water companies are required to continue to maintain consistency. However, this goal is of course dealing with disturbances that can lead to a decrease in the consistency of the quality and quantity of drinking water

The results of this study found that the scale of RTO of an event must be overcome less than 4 hours and tolerance of up to 8 hours, maximum tolerance that can be tolerated (MTPD) criteria is almost similar to RTO, RPO as an illustration of the condition of how much clean water services that can be secured and backed up at the time of the disturbance, if the incident that needs to be recovered is only around 5\% (condition is still safe $>95 \%$ ) then the disturbance is still in the event category or the condition is still secure $>90 \%$, then the incident and resource availability category is categorized if it is still available above $90 \%$, then the event is still safe (normal). This study also found the criteria and categories of events (events, incidents, crisis and disaster). Based on the four indicators of RTO, MTPD, RPO, and the availability of these resources with FIS method produces $4^{4}=256$ rule base "IF-THEN" to determine the level of crisis events in drinking water management companies and produce an early warning 
system simulation model for decision making status of drinking water management crisis in drinking water company.

The simulation model of the early warning system at a drinking water company (PAM) can be a reference in decision making for company management in determining the status or crisis situation of the drinking water services provided and can be a guide for the bricks of tolerance for disturbances that are obtained. The research results are expected to provide input for drinking water companies so that they can always maintain the continuity of drinking water services, minimize operational disruption and ensure that a drinking water crisis does not occur, especially until a disaster occurs.

\section{References}

[1] Sallata,M. 2015. Konservasi da Pengelolaan Sumber Daya Air Berdasarkan Keberadaannya sebagai Sumber Daya Alam. Infor Teknis ECONI. 12(1): 75-86.

[2] Utami, S and Handayani. 2017. Optimalisasi Peran Sains dan Teknologi untuk Mewujudkan Smart City. Universitas Terbuka, Tangerang Selatan. ISBN 978-602-392-158-4.

[3] Khoirunnisa, N. 2019. Peran Penyelenggara Air Minum Dalam Meningkatkan Sistem Penyediaan Air Minum. OSF. July 8. osf.io/a6dxq.

[4] Unicef. 2012. Ringkasan Kajian: Air Bersih, Sanitasi, dan Kebersihan. Available in https://www.unicef.org/indonesia/id/AB8_-B_-Ringkasan_Kajian_Air_Bersih.pdf. [accessed in 20 July 2020].

[5] Hamzah. 2016. Mitigasi Risiko Pengelolaan Sumber Daya Air Waduk Jatiluhur dengan Pendekatan Green Business Continuity Management (GBCM). [disertation]. Bogor (ID): Postgraduate School Bogor Agricultural University.

[6] Gang C. 2011. Evaluation Model of Business Continuity Management Environment on E-Learning. International Conference on Multimedia, Software Engineering and Computing 1(128): 323-327.

[7] Coburn AW. RJS Spence, A. Pomonis. 1994. Mitigasi Bencana (Second Edition). Program Pelatihan Manajemen Bencana. UNDP. United Kingdom (UK): Cambridge Architectural Research Limited.

[8] Carter WN. 1991. Disaster Management - A Disaster Manager's Handbook. Manila (PH): Asian Development Bank.

[9] Diposaptono S. 2007. Mengantisipasi Bencana. Bogor (ID): PT Sarana Komunikasi Utama.

[10] Latief H. 2008. Pedoman Penanggulangan Dampak Kerusakan Kawasan Pesisi Akibat Bencana Gelombang Pasang Berbasis Ekosistem. Bandung (ID): Pusat Kajian Tsunami ITB.

[11] Kamisky G, Lizondo S, and Reinhart CM. 1998. Leading Indicators of Currency Crises. Staff Papers. 45 (1): $1-48$.. 
[12] Seow K. 2012. Business Continuity Management: A Strategic Approach to Managing Business Interuption Risk. Contingency Solutions. Jakarta (ID): BCM Workshop Series for Financial Institutions.

[13] Gang C. 2010. Risk Evaluation of Business Continuity Management by Using Green Technology, Ebusiness Technology and Strategy of the series Communications in Computer and Information Science 113: 86-92.

[14] Klir G, and Bo Y. 1995. Fuzzy Sets and Fuzzy Logic Theory and Application. New Jersey (US): Pretince Hall Inc.

[15] Kusumadewi S, Purnomo H. 2004. Aplikasi Logika Fuzzy Untuk Pendukung Keputusan. Yogyakarta (ID): Graha Ilmu.

[16] Marimin. 2005. Teori dan Aplikasi Sistem Pakar dalam Teknologi Manajerial. Ed. ke-3. Bogor (ID): IPB Press.

[17] Hamzah, Maarif MS, Marimin, Riany E. 2016. The risk mitigation of water management resources of Jatiluhur reservoir with the green business continuity management approach. Journal of Natural Science Research, ISSN (Paper) 22243186, 31 March 2016.

[18] Brocklehurst C, Slaymaker T. 2015. Continuity in Drinking Water Supply. PLoS Med. 12(10). Available in https://doi.org/10.1371/journal.pmed.1001894 [accessed in 2020 July 21].

[19] Yulius M, Suryani E. 2013. Kajian Kesiapan Pengelolaan Bencana pada Perusahan Daerah Air Minum (PDAM) di Kota Padang. Jurnal Teknik Industri Universitas Bung Hatta. 2(1): 49-60.

[20] Storey MV, Gaag B, and Burns B. 2011. Advance in On-Line Drinking Water Quality Monitoring and Early Warning Systems. Water Research. 45(2):1-7.

[21] Levine AB, Liu S, and Vince F. 2012. Drinking Water Source Contamination Early Warning System and Modelling in China: A Review. International Journal of Environmenntal Pollution and Remediation. 1(1):13-19.

[22] Gulley N and Jang JS. 1999. Fuzzy Logic Tool Box. USA: The Mathworks Inc.

[23] Wordford, BJ. 2000. A Comparison of ANFIS and FuNN. New Zealand: University of Otago.

[24] Boehmer W. 2009. Survivability and business continuity management system according to BS 25999. IEEE Computer Society: 142- 147

[25] Kleef JA and Roome NJ. 2007. Developing Capabilities and Competence for Sustainable Business Management as Innovation: AResearch Agenda. Journal if Cleaner Production. 15(1):38-51.

[26] Hamzah, Maarif MS, Marimin, Riany E. 2016. Status Mutu Air Waduk Jatiluhur dan Ancaman terhadap Proses Bisnis Vital. Jurnal Sumber Daya Air, Pusat Penelitian Sumber Daya Air, Badan Penelitian dan Pengembangan, Kementerian PU dan Perumahan Rakyat Republik Indonesia Volume 12 (1): 47-60. 